\title{
FLOOD RISK ANALYSIS IN SUCEAVA CITY, APPLIED FOR ITS`MAIN \\ RIVER COURSE
}

DOI: http://dx.doi.org/10.18509/GBP.2016.15

UDC: 627.51-047.44(498)

\section{PhD Student Marina Iosub, PhD Student Anamaria Ioana Tomaşciuc, PhD Student Oana Elena Hapciuc, PhD Student Andrei Enea}

Alexandru Ioan Cuza University of Iasi, Faculty of Geography and Geology, Department of Geography, Iasi, Romania

\begin{abstract}
Suceava municipality is located in the North-Eastern development region, on the valley of Suceava river. The spatial expansion has generated the exposure of the city to several risk factors, one of the most frequent being the flood risk. During the time interval taken into consideration, the floods that took place in the drainage basin of Suceava river, in the month of July 2008, can be emphasised, both from a quantitative point of view, and from the point of view of the damages caused. At the Itcani hydrographical station, of great significance for Suceava municipality, the historic flow rate of $1710 \mathrm{~m}^{3} / \mathrm{s}$ was recorded, at the $27^{\text {th }}$ July 2008 , with an associated water level of $820 \mathrm{~cm}$. The floods have affected mostly the commercial spaces, that have been built during the last years along the floodplain of Suceava river. Taking this into consideration, the hereby study intends to identify the areas vulnerable to flooding, along the course of the Suceava river, by applying the HEC-RAS simulation model and correlating the obtained results with the spatial dynamic of the built-up areas, in the post-communist period.
\end{abstract}

Keywords: flood, HEC-RAS, risk, Suceava river, urban sprawl.

\section{INTRODUCTION}

During the last 20 years, the majority of settlements located in the hydrographic basin of the Suceava river were affected by dangerous meteorological and hydrological phenomena. This situation is given by both natural factors, associated with the climatic conditions that generate large amounts of precipitations, and antrophogenic factors, through massive deforestations, poor maintenance of river beds, the construction of embankments and protective structures, bank erosion, the existence of unauthorised constructions in the floodplain and several investments that weren't finished in the area $[1,2]$.

The economic development and expansion of the urban space, correlated with the deforestation process, has lead to the emphasis of hydroclimatic phenomena in the drainage basins located in the north-eastern part of Romania [3]. The identification of flood vulnerable areas, in a specific city, and establishment of adequate measures for reducing the flood risk, can lead to the diminution of human loss and property damage. The unorganized territorial expansion of rural settlements (and urban, as well) in Romania, over the last 60 years, has lead to the transformation of river floodplains into inhabited areas. This has determined the accentuated increase of exposure of the settlements to the flood risk. The current case study is based on the flood that took place 
in July 2008, and addressess the impact it had on the buildings that had been constructed in the vecinity of Suceava river, and the cuantification of the territorial expansion, over the floodplain area. For generating the flood simulation, the HEC-RAS software was utilized. This choice of program is favoured by the possibility it offers to generate both 1D simulations, and 2D [4]. Furthermore, the existence of the digital terrain model at a scale of 1:5000, is another argument in favour of applying this particular model [5].

\section{STUDY AREA AND METHODOLOGY}

Suceava municipality is located, from a geographical point of view, in the Suceava plateau, inside the hydrological basin of Suceava river, which is the main water course that flows along this city. Out of all the limitrophe administrative units, Suceava river crosses the northern part of Ipotesti commune, and the boundary between Scheia and Patrauti communes. From an administrative point of view, Suceava municipality is part of the North-Eastern Development Region, in the South-Eastern part of Suceava county, also being the county residence city (fig.1).

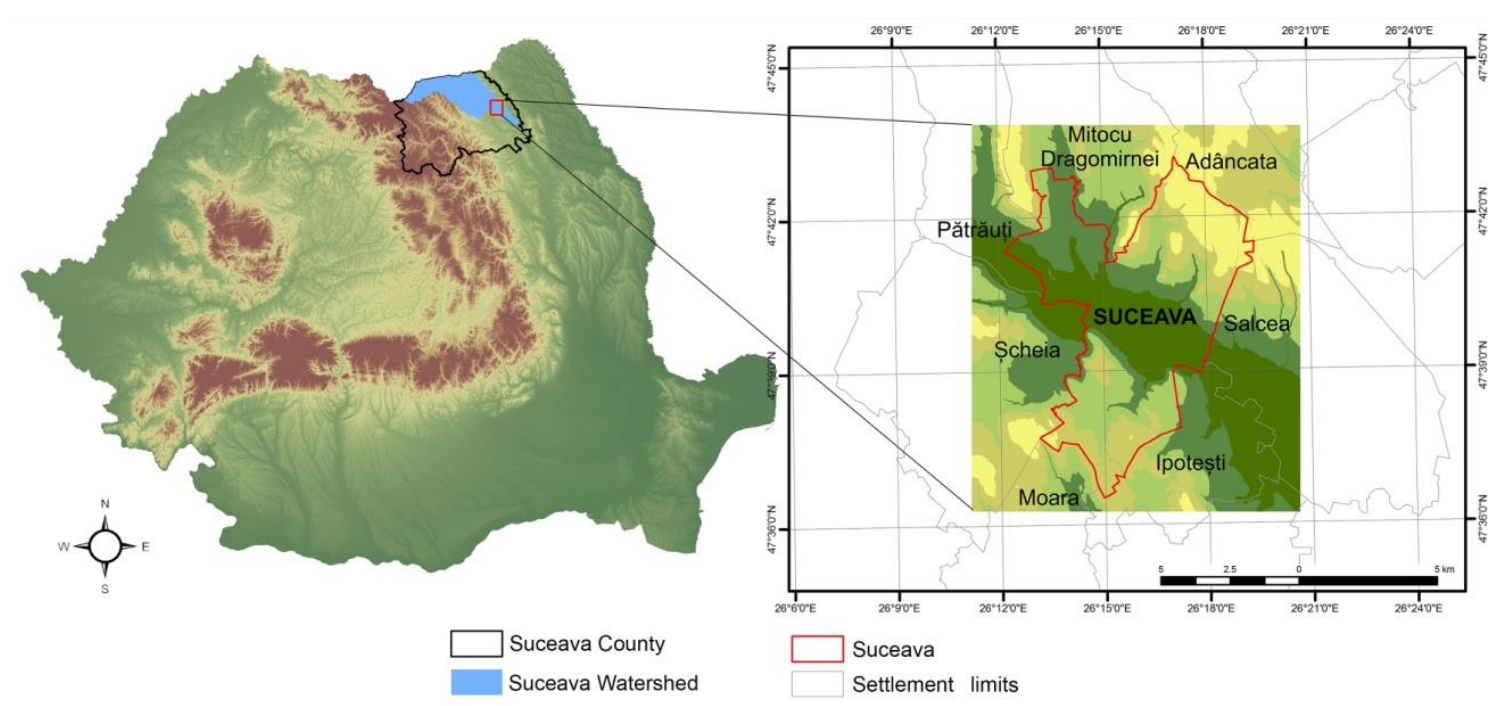

Figure 1. Geographical location of the study area

Suceava river springs from an altitude of 1250 meters, in the region of Obcinele Bucovinei, its hydrological basin spreading on a surface of $2625 \mathrm{~km}^{2}$, and the water course is $262 \mathrm{~km}$ long. The average multi-annuall flow rate for the river is $17,9 \mathrm{~m}^{3} / \mathrm{s}$, at the confluence with Siret river.

In the area defined by Suceava city, the river valley is emphasized in the field, by its large widths, and it was named "SSesul Sucevei". Along this sector, the floodplain of the Suceava river, prone to flooding in the past years, has been mostly modified by man, and has undergone several constructions.

By analizing the data at the Iţcani hydrometrical station, over a period of 59 years (1955 - 2011), the fact that there have been more floods with a local or general character (out of which some had catastrophic effects), can be observed. The largest, most important floods that have taken place here, in Suceava drainage basin, during the analysed time period, were recorded in 1955, 1969, 1970, 1978, 1991 and 2008 (fig. 2). 


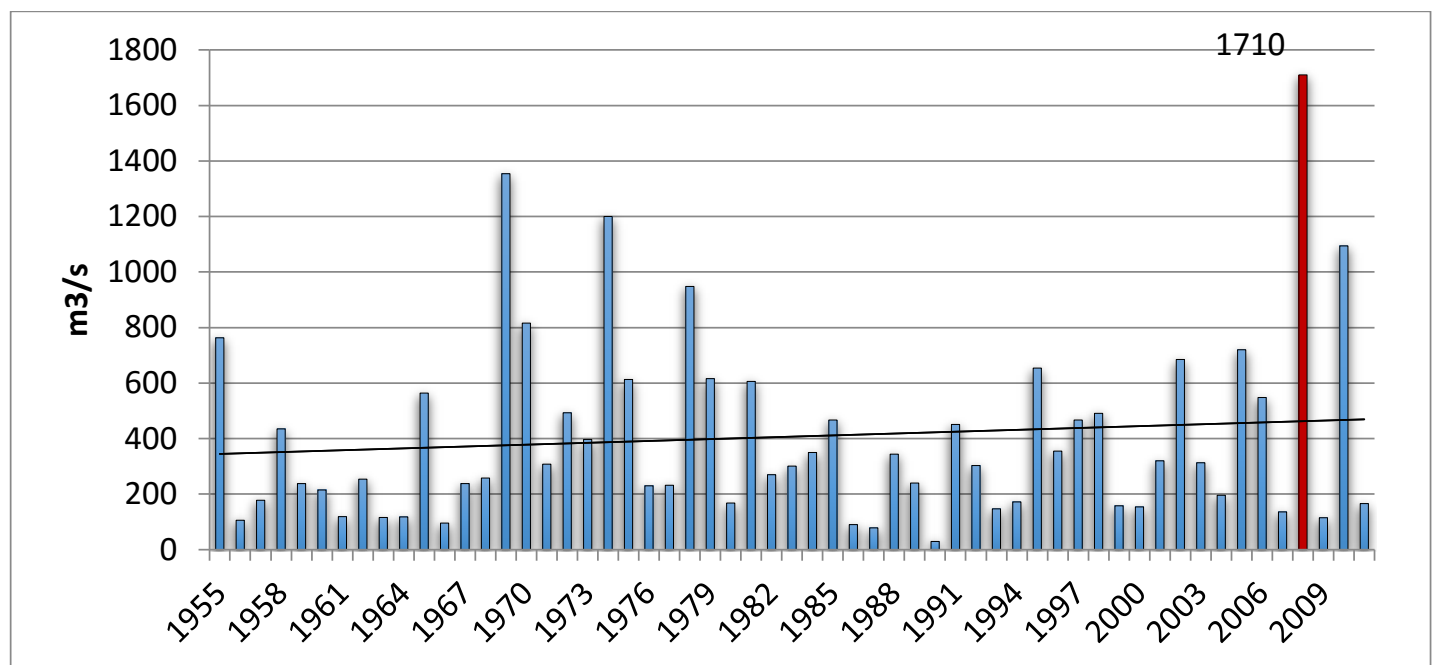

Figure 2. The maximum monthly flow rates, at Itcani hydrometrical station, in Suceava drainage basin, between $1952-2011$

The year of 2008 can be considered to be a reference point in flood analysis, along the Suceava river, its' flow rate surpassing all the anticipated values, up to that, specific, moment. The temporal expansion of the flood was measured at 4 days, out of which the runoff that had a greater flow rate than $1000 \mathrm{~m}^{3} / \mathrm{s}$ lasted 37 hours (cumulated time), during which there were a total of two flood peaks, both of them surpassing $1400 \mathrm{~m}^{3} / \mathrm{s}$, which is the maximum value recorded up to that time. A value of $1488 \mathrm{~m}^{3} / \mathrm{s}$ was recorded for the first flood wave, on the $25^{\text {th }}$ of July, and the second flood wave reached a maximum of $1710 \mathrm{~m}^{3} / \mathrm{s}$, at 4:00 A.M., on the $27^{\text {th }}$ of July 2008 (fig. 3).

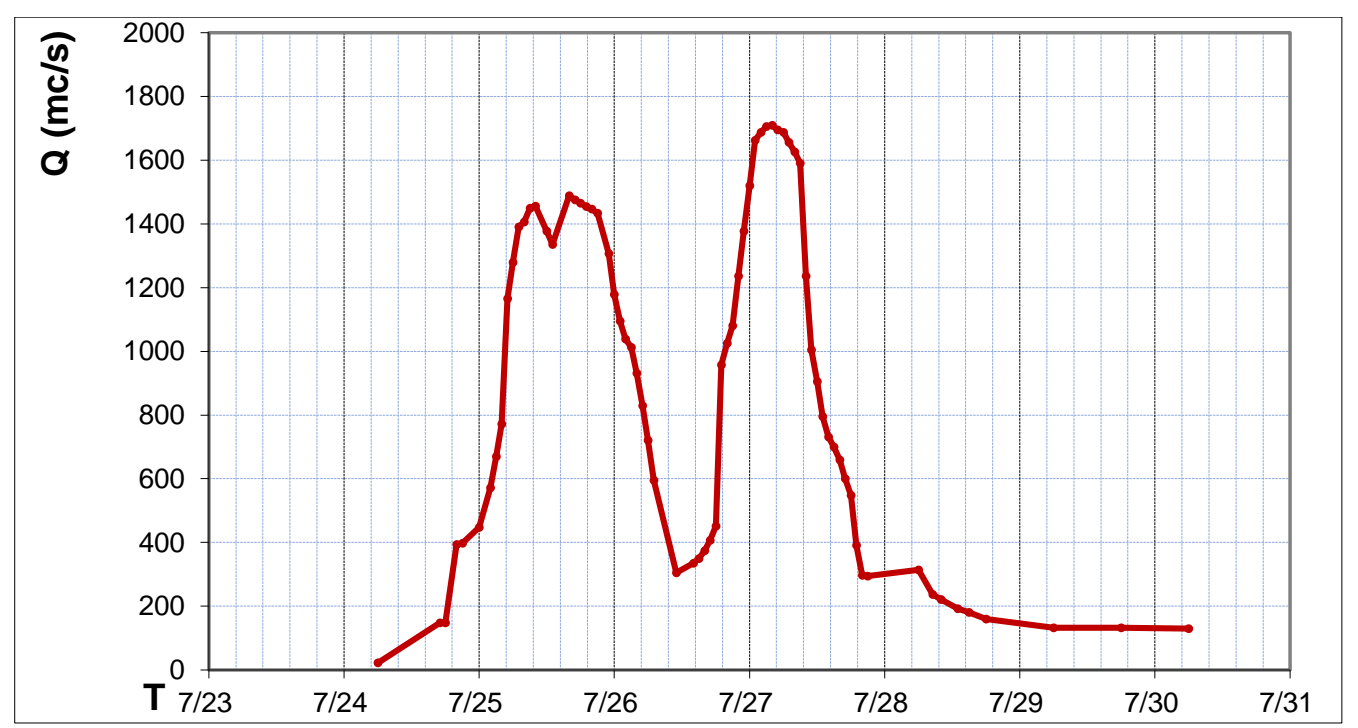

Figure 3. Flood hydrograph (July 2008) at Itcani hydrometrical station, Suceava drainage basin

The main events that have determined the occurrence of such a large value flow rate are the soil wetness value before this event and the spatial distribution of the precipitations. This year has been characterized as a rainy one, and the precipitations have determined a risen value of soil humidity. The large quantity of precipitations is due to a retrograde cyclone, which has manifested in the Eastern region of the Oriental Carpathian mountains, during 22-27 July 2008, with strong rainfall that occurred in two periods: 2425 , and 25-26 July [6]. The combination of the soil, that was already saturated with water, 
with the retrograde cyclone that has brought a significant quantity of rainfall, has lead to the manifestation of a flood with a flow rate which has surpassed all the previous, recorded values.

In order to put into context the flood risk for Suceava municipality, in a current situation, it was necessary to analyze the spatial expansion of the city, taking into consideration the dynamic character of this phenomena, in the post-communist period. Multi-temporal cartographic materials have been used to identify the residential and commercial spaces that were newly built. The first thematic layer that has been used is given by the constructions drawn by Vasile Crăciunescu, from topographic plans, at a 1:5000 scale, from the 1980's [7]. This dataset has been updated, by comparing them to orthophoto imagery, from 2005 and 2012, which was obtained by making several printscreens (from the ANCPI portal-viewer) at the same resolution, until the entire study area was covered, and then georeferencing and joining them. The manipulation of the spatial data, as well as the extraction of statistical datasets, generated by the creation of the database, which was necessary to analyze the dynamic processes, was done with the use of ArcGis.

The data required for running the flood simulation, such as flow rates, water level in several control sections, and the dimensions of the hydrotechnical constructions in the area, have been obtained from the Siret Water Basin Administration, Bacau.

The flood simulation has been computed with the help of Hec-Ras, ArcGis software and the HEC-GeoRas extension. This software has a widely spread usage, and its results are valid, from a scientific standpoint [8].

The workflow methodology is made out of three, large steps: preprocessing, processing and postprocessing (fig. 4).

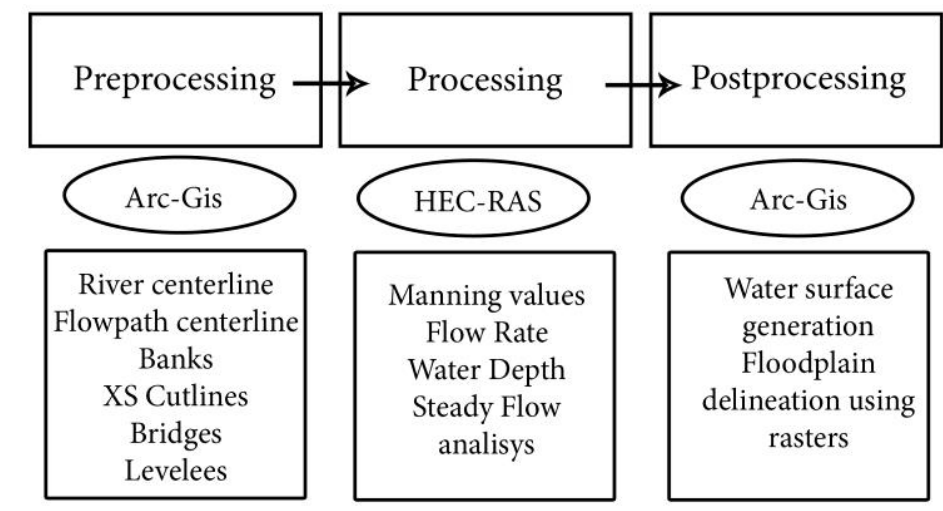

Figure 4. Workflow for applying the HEC-RAS simulation model

During the first stage, several layers related to the geometric description of the simulation project are drawn. The geometric description is defined in the international literature as "just a skeleton, that defines the study area for which the numerical modeling of the simulation will be done [9]. The workflow in the current study consists of characterizing the natural and anthropogenic langscape: including data about the Suceava river, and its territorial extent, river banks, bridges and embankments. The base layer, from which all the data has been derived, is given by the digital elevation model generated from topographical maps, at a 1:5000 scale, in TIN (Triangulated Irregular Network) format. By inserting the data, the cross-sections have been generated, which have the purpose to offer information regarding the terrain, and assist in the simulation project. The analyzed area has a length of $16.8 \mathrm{~km}$, and corresponds to the transit area of Suceava river, through 
the municipality named after this river. The total number of cross-sections made is 329 , with a 50 meter distance between them.

During the second stage, the data was exported into HEC-RAS software. Therefore, a work project has been created, in which all the data related to roughness, maximum flow rates for different occurrence probabilities, water level in control sections, dimensional values for hydrotechnical constructions etc. The flood simulation was done assuming the logic of a constant flow of water (Steady flow).

The values of Manning's roughness coefficients were chosen according to the river bed characteristics, the landscape and the vegetation that had grown in the vicinity of the river. According to the values calculated by Chow (1959), from Manning's equation, for different drainage canals, the studied section of Suceava river has been associated with the following values: $0.03,0.035 \mathrm{si} 0.04$ [10]. As far as establishing the flood simulation limits, the values of the flow rate recorded during the 2008 flood were taken into consideration, and the water column level was calculated with the "Normal Depth" function, the chosen value being $0.03 \mathrm{~m} / \mathrm{m}$.

Running the flood simulation in the Steady Flow menu resulted in obtaining the floodprone area and profile observations of its evolution. In order for the graphical form of the results to be as suggestive, as possible, they are exported into ArcGis, where two maps can be computed: the territorial extent of the flood (Water Surface Generation), and the water depth map (Flood plain delineation using raster).

\section{THE SPATIAL DYNAMIC OF SUCEAVA MUNICIPALITY}

In a similar manner to the other major cities in Romania, Suceava municipality has confronted, during the post-communist period, with modifications in the dynamic and the structure of the city. The spatial extension of Suceava municipality has determined its exposure to numerous risk situations, the most frequent and visible being the risk to flooding.

The territorial evolution of Suceava municipality is the result of the functional development of the settlement in time and space, of the old, urban functionalities, and also of the ones it has accumulated during time, and its evolution process, as well as their interconditioning with the demographic factor [11]. Regarding the spatial dynamics of the municipality in the post-communist period, several development directions can be identified: the densification of the built-up areas, from 690 constructions $/ \mathrm{km}^{2}$, registered at the population census in 1992, to 777 constructions $/ \mathrm{km}^{2}$, registered at the census in 2011 (REC 1992, REC 2011), in the administrative limits of the city, and the periurbanization, which manifests through the expansion of the commercial spaces and the living areas, generated by the city, in the rural spaces, next to them.

Inside the administrative boundaries, the decay of several industrial areas can be observed, many of them being demolished and gradually reconverted into commercial areas (ex. The current placement of the Iulius Mall, on the Suceava river floodplain). In the context of territorial evolution from the post-socialist period, in the Suceava floodplain, numerous constructed spaces have been developed, especially with commercial destination. Another characteristic of the current dynamic of Suceava municipality is given by the occurrence of residential areas, similar to those located in the rural periurban space (in Burdujeni neighbourhood, at the boundary with Salcea and Ipotesti communes), which generally extend on the administrative territory of the limitrophe communes. The expansion of the built-up area has reached beyond the 
administrative limits of the municipality, the periurbanization process being best emphasized in the Șcheia, Moara and Ipotești communes (Fig.5). By applying the ANN index (Average Nearest Neighbor), included in the tool package, offered by ArcGis software, it has been proved that the expansion of the constructed area, after 1990 is not random at all, but takes place according to a development pattern (,clustered” type).

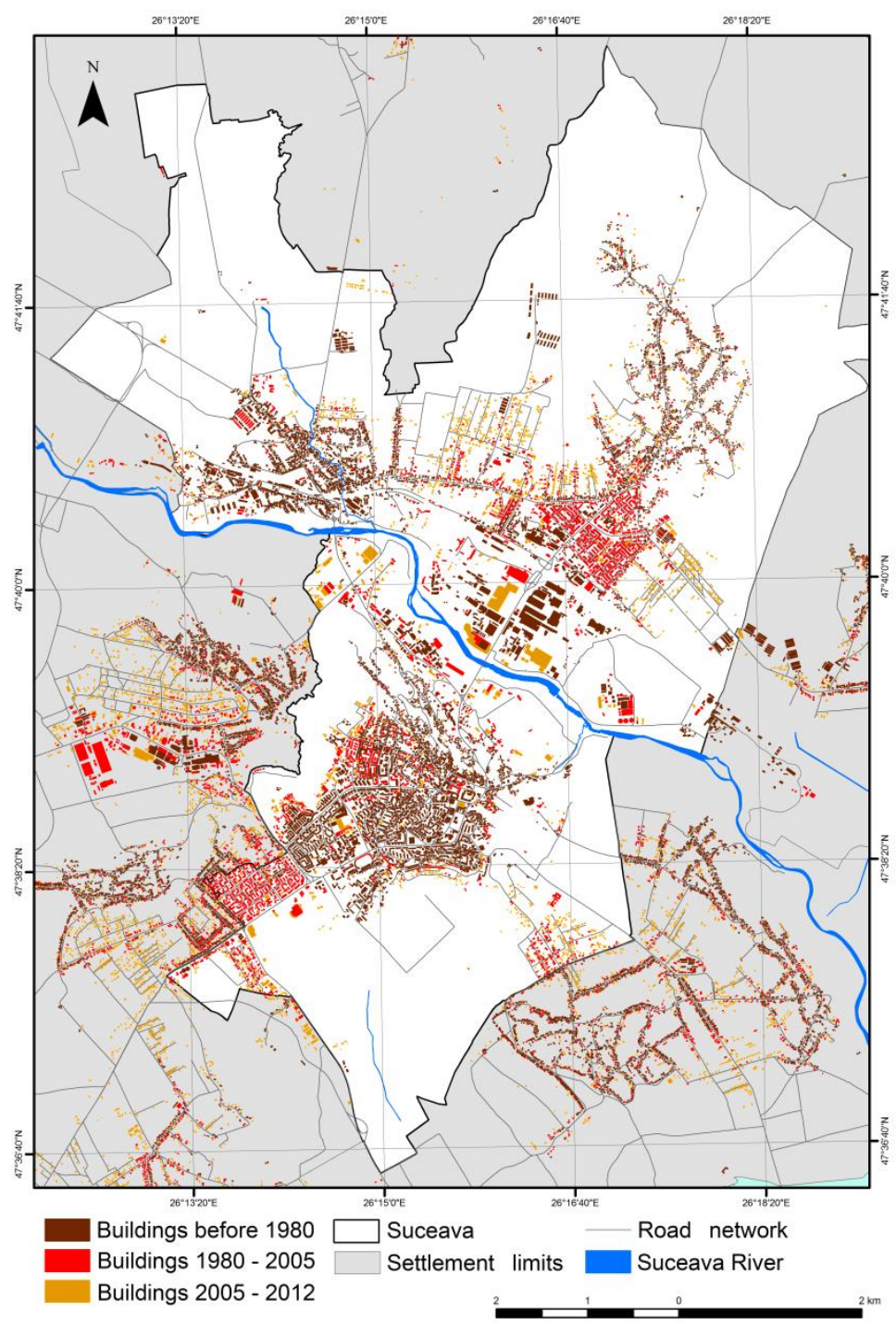

Figure 5. The spatial dynamic of Suceava municipality (1980-2012)

\section{RESULTS AND DISCUSSION}

The terrain flooded by Suceava river, along the studied sector, expands over an area of $3.82 \mathrm{~km}^{2}$. The maximum water depth, calculated according to the model, is $9.94 \mathrm{~m}$, and the average is $4.7 \mathrm{~m}$. The water level distribution is a Gaussian-type one, with the largest weight for water depth being in the 3-5 meter interval. In the terrain, the largest depth values are recorded at the output of the river from Suceava municipality (fig. 6). 


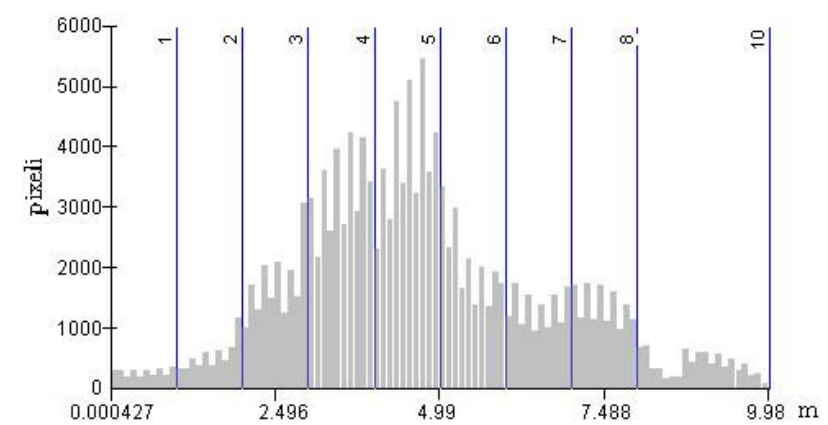

Figure 6. Water level histogram for the Suceava municipality sector

Following the analysis of the territorial expansion of the buildings, during 1980-2012, and the overlapping of the flood-prone areas on them, the fact that the buildings constructed after 1980 are included in this area (especially the higher density buildings, constructed between 2005-2012) can be observed (fig. 7).

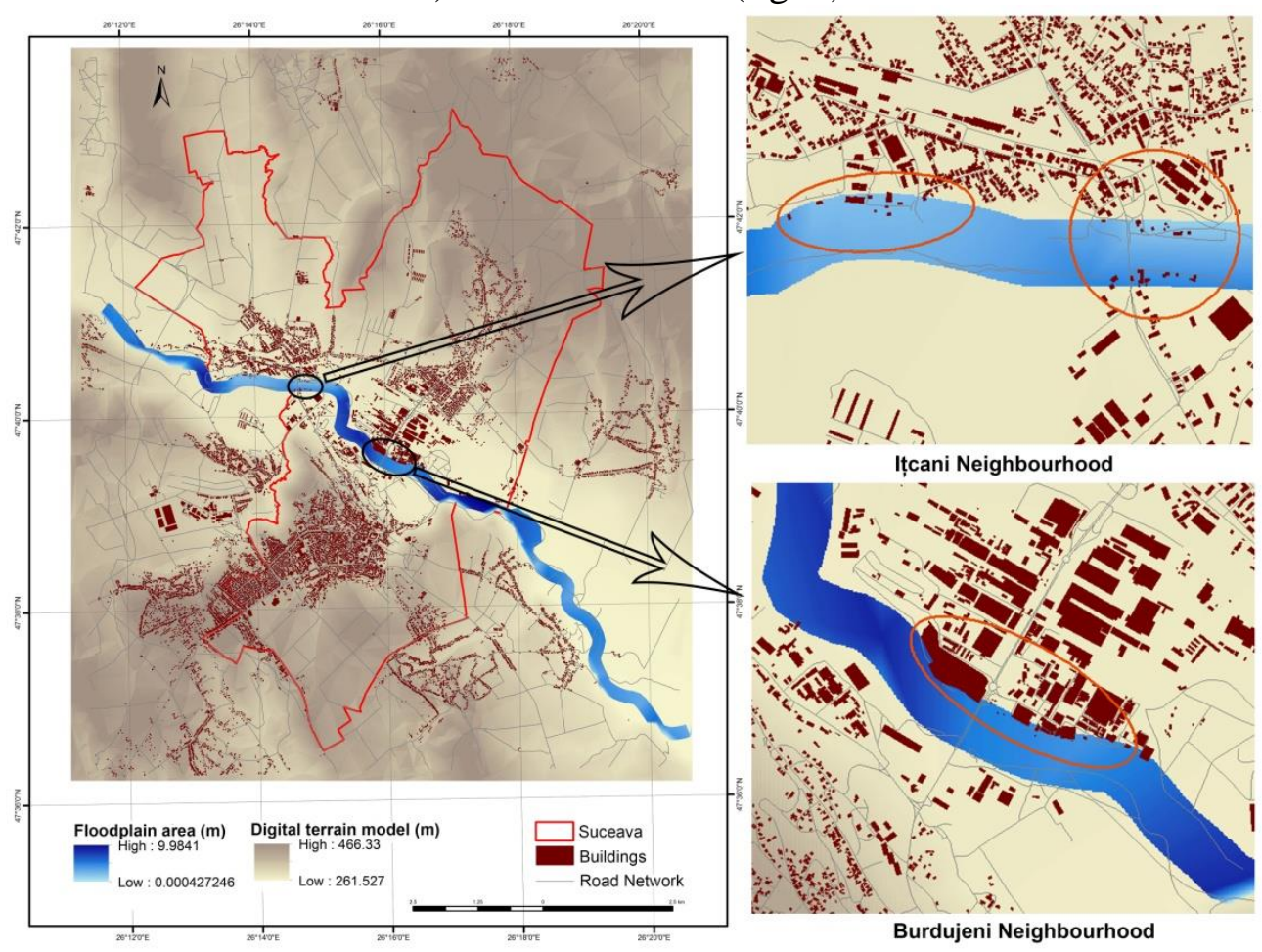

Figure 7. Flood area generated through mathematical simulations, in HEC-RAS

In this case, the number of buildings susceptible to flooding, constructed up to 1980, is 17, and those constructed after 1980 is 29 (18 between 1980-2006 and 11 between 20062012). The large number of newly constructed buildings indicates a chaotic territorial expansion in the recent period, which do not take into consideration safety rules. The problem is greater, considering the placement of large-scale commercial units in the risk area, which record major economic losses.

The fact that part of the buildings constructed after the flood are in the first risk category, emphasizes the lack of involvement of the authorities. After 2005, neither the maximum water levels that Suceava river can reach were not taken into consideration, nor the spatial extent that a flood can reach. Therefore, the maximum level recorded in 2008 wasn't taken 
into consideration for flood predictions, making the urban planning poorly written, according to other types of flood risk considerations.

\section{CONCLUSIONS}

By generating the hydrological risk map for Suceava municipality, it can be concluded that this method, although using relatively little data, can model with a reasonably high accuracy, the hydrological risk events. The hydrological model made, by applying the HEC-RAS 1D flood simulation model, has been $90 \%$ successfully validated, taking into account the damage recorded by authorities, after the flood that took place in July 2008, as well as the field observations. This particular model helps to prevent floods, or create protection plans in the case of extreme hydrological events.

The results obtained through HEC-RAS modeling correspond to the predictions calculated by the Siret Water Basin Administration, according to the Flood Directive 2007/60/CE.

\section{REFERENCES}

[1] Mihăilă D., Budui V., Cristea I.A., Tănasă I., 2006. Considerații asupra riscurilor climatice în județul Suceava, Analele Universității "Ștefan cel Mare” Suceava, Secțiunea Geografie, anul XV.

[2] Hociung C., Băișanu Ș.A., 2009. "Județul Suceava - Riscuri și vulnerabilități. Fenomene excepționale de risc", Editura Lidana, Suceava.

[3] Hapciuc O.E., Minea I., Iosub M., Romanescu Gh., 2015. The role of the hydroclimatic conditions in causing high floods in the Sucevița river catchment, Air and water components of the environment, Editura Presa Universitară Clujeană, Cluj Napoca, pag. $201-208$, ISSN: 2067-743X.

[4] Venkatesh Merwade, 2012. Tutorial on using HEC-GeoRAS with ArcGIS 10 and HEC-RAS Modeling

[5] Bates, P.D., Marks, K.J., Horritt, M.S., 2002. Optimal use of high-resolution topographic data in flood inundation models. Hydrological Processes 17 (3), 537-557.

[6] Romanescu G., Stoleriu C., Romanescu A.M., 2011, Water reservoirs and the risk of accidental flood occurrence. Case study: Stânca-Costeşti reservoir and the historical floods of the Prut river in the period July-August 2008, Romania, Hydrological Processes, Wiley, Vol. 25, Nr. 13, 2056-2070 p.

[7] http://www.geo-spatial.org/download/seturi-date-geospatiale-locale

[8] Iosub M., Minea I., Hapciuc O.E., Romanescu G., 2015. The Use Of HEC-RAS Modelling in Flood Risk Analysis, Air and water components of the environment, Editura Presa Universitară Clujeană, Cluj Napoca, pag. 315 - 322, ISSN: 2067-743X.

[9] Cook A., Merwade V., 2009, Effect of topographic data, geometric configuration and modeling approach on flood inundation mapping, Journal of Hydrology, Elsevier, vol. 377, 137-142 p.

[10] Chow V.T., 1959, Open-channel hydraulics: New York, McGraw-Hill, 680 p.

[11] Emandi E.I., Ceauşu M.S., 1991, Să nu dărâmi, dacă nu ştii să construieşti, Editura "Glasul Bucovinei”, Rădăuţi - Iaşi 